\title{
Factors Influencing Indigenous Technological Learning and Innovations in the Auto-Mechanic Industry in Nigeria
}

\author{
B. A. Oluwale ${ }^{*}$,M. O. Ilori, T. O. Oyebisi
}

African Institute for Science Policy and Innovation, Obafemi Awolowo University, Ile-Ife, Nigeria

\begin{abstract}
Nigeria's economy moves on wheels and the auto-mechanics, in spite of their low levels of education, have kept the various brands of imported vehicles running in an era of harsh economic climate. Local innovations and adaptations are being generated to keep the industry going. It therefore becomes imperative to study the factors that influence these technological learning and innovations in the industry. This is with a view to encouraging appropriate policy formulation in vocational training that will further impact on the industry. The result showed that there was a significant $(F=86.70, p<0.05)$ difference in the mean ratings of the factors influencing technological learning and innovations in the industry. These factors include age, sex, period of apprenticeship, level of education, and language of instruction.
\end{abstract}

Keywords Indigenous, Technological Learning, Innovations, Auto-Mechanic Industry, Nigeria

\section{Introduction}

Technological learning has been defined as any process that strengthens the technological capabilities for generating and managing technical change[1]. Two categories of learning have been identified[6]. The first consists of the methods by which an individual firm or an economy accumulates a set of skills through education, training and experience. This can be by hiring of skills and "learning by doing"[1]. The second is technical change which has been further broken down[13] into:

( i ) Elementary learning which involves "learning-by-do ing” and "learning-by-adapting”

(ii ) Intermediate learning which consists of "learning-by -design” and "learning-by-improved design”

(iii) Advanced learning which is "learning-by-setting-up a complete production system”.

Two types of learning have been identified: non-formal and formal[20]. It was observed that the growth of small firms rely greatly on the non-formal (learning-by-doing) type especially Africa's small firms which are rooted in crafts apprenticeship. In India, for example, informal training is recognized as the dominant skill acquisition strategy for the majority of workers and this applies to many other economically developing countries[5]. Thus the importance of learning was aptly noted[2] by the assertion that:

“Technological progress, innovation and economic development are however, correlated not with investment in

* Corresponding author:

adegbolaoluwale@gmail.com (B. A. Oluwale)

Published online at http://journal.sapub.org/mm

Copyright (C 2012 Scientific \& Academic Publishing. All Rights Reserved science or R\&D a lone, but with learn ing”.

The automobile repair industry in Nigeria appears to be at the first level of the above categorization i.e. "learning-by-doing" and "learning-by-adapting". This elementary level of learning was also characteristic of the Industrial Revolution in Britain in the $18^{\text {th }}$ century before the establishment of theory-based scientific institutions[20].

\subsection{Indigenous Learning}

Indigenous peoples have been defined[12] as

(a) "Tribal peoples whose social, cultural and economic conditions distinguish them from other sectors of the national community, and whose status is regulated wholly or partially by their own customs or traditions or by special laws or regulations”.

(b) "Peoples who a re regarded as indigenous on account of their descent from the populations which inhabit the country, or a geographical region to which the country belongs, at the time of conquest or colonization or the establishment of permanent state boundaries and who, irrespective of their legal status, retain some or all of their own social, economic, cultural and political institutions”.

Indigenous knowledge has been described as "native ways of knowing”[23]. This knowledge reflect the dyna mic way in which the residents of an area have come to understand themselves in relation to their natural environment and how they organize that folk knowledge of flora and fauna, cultural beliefs and history to enhance their lives[23]. It has been noted[13] that an ominous gap exists between Western and non-Western interpretation of reality with particular reference to school learning. Learning happens not just in regimented settings such as schools or in school-aged children[8]. Most learning does not occur in formal learning 
situations, but mainly informally[15, 24]. Thus it was asserted that one's culture programs a person's thoughts, feelings, and actions. The Western approach to African and non-Western education, science and knowledge has thus generally been substitutional rather than inclusive. Th is was noted[9] thus: “. .. attitude and often the intent of Western education has been that a "primitive" or "decadent" civilization is to be replaced by a more "modern" and "better" one".

It has been observed[18] that central to the learners' cultural and social experiences are the language they use in their everyday interactions. The identity of a people is often intimately related to their language[16]. This notion is further strengthened by the view that language is interwoven with the process of knowledge generation[25]. The experiences of such countries like Japan and Korea where economic and technological developments have been achieved without recourse to European languages is instructive[7]. In fact, studies conducted in several African countries report the negative effects of teaching in foreign languages[3]. It has been observed that Kenya's educational system has not been able to tailor its content and pedagogy to the socio-economic and cultural realities of its people capable of developing local solutions for local problems [19]. Similar conditions are obtainable in Tanzania and other African countries. This has been succinctly expressed[22] thus:

“...we believe that it is important to broaden the concept of education to include all systems of knowledge, with recognition of the value of indigenous or local knowledge within the education process".

Consequently, modern African education has come to be characterized by unabashed imitativeness with little attempt of domesticating the Western-type education[17]. The above situation has been leading to devaluation or annihilation of African creativity, agency and value systems [20].

There is no doubt that the vast majority of African auto-mechanics have little or no formal education. In essence, they have had to rely more on the non-formal indigenous method of learning which has kept the industry going. This has been manifested further in ingeniously coining of names for automobile tools and engine parts. The objective of this study, therefore, is to assess the factors influencing technological learning and innovations in the auto-mechanic industry in Southwestern Nigeria.

\section{Methodology}

It has been postulated [11] that an individual with skills requires an organization or institution, and purpose to express hims elf. Furthermo re, as a nation's population grows there is a growth of labour force which is essentially unskilled. The unskilled labour pass through a period of training which may be subject to age or educational background at the point of entry into apprenticeship. The resultant effect at the end of training or apprenticeship is the growth of the stock of skilled labour. The conceptual framework for this study takes its basis from the above statement.

The study covered auto-mechanics in Southwestern Nigeria specifically Osun, Ogun and Lagos states. The respondents were master mechanics, journeymen and mechanic apprentices. Questionnaire were administered by hand delivery in a person-to-person mode using research assistants who had been trained before proceeding to the field. A total of 712 copies of questionnaire were administered out of which 385 (54.07\%) were admin istered to master mechanics and 327 (45.93\%) to journeymen and apprentices. The questionnaire comprised of both structured and unstructured questions. The questionnaire elicited such information as age, sex, period of apprenticeship, level of education, and language of instruction.

Data obtained were analyzed using descriptive statistics such as percentages, frequencies, and means on the one hand; and inferential statistics such as analysis of variance (ANOVA) by employing Standard Package for Social Scientists (SPSS). Post-hoc tests were carried out using Duncan Multiple Range Test.

\section{Results and Discussions}

\subsection{Language of Instruction of Master Auto-Mechanics}

Tables 1 and 2 depict the language of instruction used to train the master auto-mechanics during their period of apprenticeship, and the medium of instruction they were using to train their own apprentices respectively. Most (96.32\%) of the master mechanics were trained using the Yoruba language as a medium of instruction. About $97.9 \%$ of them also employed the same language to train their own apprentices. This is not unexpected since most of the master craftsmen and the apprentices had low Western academic qualifications.

Most (90.82\%) journeymen and apprentices indicated that they preferred the Yoruba language as the language of instruction in the auto-mechanic trade (Table 3) while only 4.08\% preferred the English language for instruction. Comprehension and learning are easier when a person is instructed in his own language. This has been attested to by findings in East Asia where Japanese and Chinese students were first instructed in their own indigenous languages [4]. It has been observed[4] that in virtually all the advanced countries of the world, children are first and foremost educated in their mother tongue, USA, Britain, France and Germany being typical examples. This has no doubt aided understanding and assimilation of technology in those countries.

\subsection{Factors that Aid Apprentices' Learning}

The factors that aid apprentices' learning as perceived by master mechanics are presented in Table 4. Five of the major factors include age, sex or gender, period of apprenticeship, education and language of instruction. The factors were 
examined on a 5 - point Likert scale with strongly agree assigned 5 points and undecided assigned 0 .

There was a significant $(\mathrm{F}=86.70, \mathrm{p}<0.05)$ difference in the mean ratings of these factors. However, the mean ratings of older apprentices learning better (4.49), male apprentices learning better (4.89), staying longer and learning better (4.59), Yoruba language aiding learning (4.99), pidgin English aiding learning (4.20) and English language aiding learning (4.57) were significantly the same. It can thus be inferred that the master mechanics agreed that older apprentices (above 18 years) learned better; that male apprentices learned better; that the longer the period of apprenticeship, the better the knowledge acquired by the apprentices. This compares well with the learning curve theory that states that the longer a person performs a task, the better he gets at it. So me of the auto-mechanics believed that as apprentices stay longer with their masters, they acquire more tacit knowledge from some uncommon challenges which enrich their skills. This has been corroborated by the observation that among the several channels of learning in Nigerian firms, apprenticeship system of training plays a crucial role[21]. Similarly, the learning triangle has been observed to consist of theoretical, vocational, and experimental forms[10]. Learning, in the African context, is thus largely tacit in nature, with the master craftsman passing on knowledge to the apprentices. These ultimately assist the latter in building up their confidence on the job. The importance of tacit knowledge to national economic development has similarly been reaffirmed in Greece[26]. It was observed that the human resource potential is not a simple outcome of the education system but a web of complex process that involves tacit knowledge, learning by doing and on-the-job training.

Table 1. Language of instruction used to train master mechanics

\begin{tabular}{ccccc}
\hline Language of instruction & Osun & Ogun & Lagos & Total \\
\hline Yoruba & 135 & 112 & 93 & $340(96.32 \%)$ \\
Igbo & - & - & 1 & $1(0.28 \%)$ \\
Hausa & 1 & - & - & $1(0.28 \%)$ \\
Pidgin English & 2 & - & 3 & $5(1.42 \%)$ \\
English & 2 & - & 4 & $6(1.70 \%)$ \\
Total & 140 & 112 & 101 & $\mathrm{~N}=353$ \\
\hline
\end{tabular}

Source: Field Survey (2009)

Table 2. Language master mechanics use to instruct apprentices

\begin{tabular}{ccccc}
\hline Language of instruction & Osun & Ogun & Lagos & Total \\
\hline 1. Yoruba & 131 & 108 & 94 & $333(97.94 \%)$ \\
Igbo & - & - & - & - \\
Hausa & - & - & - & - \\
Pidgin English & 1 & 1 & - & $2(0.58 \%)$ \\
English & 1 & - & 4 & $5(1.47 \%)$ \\
Total & 133 & 109 & 98 & $\mathrm{~N}=340$ \\
\hline
\end{tabular}

Source: Field Survey (2009)

Table 3. Preferred language of instruction by journeymen and apprentices

\begin{tabular}{|c|c|c|c|c|c|c|c|}
\hline & Osun & $\%$ & Ogun & $\%$ & Lagos & $\%$ & Total \\
\hline Yoruba & 130 & 92.86 & \multicolumn{2}{|c|}{71} & \multicolumn{2}{|l|}{66} & 267 (90.82\%) \\
\hline Igbo & 1 & 0.71 & \multicolumn{2}{|c|}{-} & \multicolumn{2}{|l|}{2} & 3 (1.02\%) \\
\hline Hausa & - & - & \multicolumn{2}{|c|}{-} & \multicolumn{2}{|l|}{1} & 1 (0.34\%) \\
\hline Pigdin English & 1 & 0.71 & \multicolumn{2}{|c|}{-} & \multicolumn{2}{|l|}{10} & 11(3.74\%) \\
\hline English & 8 & 5.71 & \multicolumn{2}{|c|}{-} & \multicolumn{2}{|l|}{4} & $12(4.08 \%)$ \\
\hline Total & \multicolumn{2}{|c|}{140} & 71 & & \multicolumn{2}{|c|}{83} & $\mathrm{~N}=294$ \\
\hline
\end{tabular}

Source: Field Survey (2009)

Table 4. Factorst hat aid apprentices' learning as perceived by master mechanics

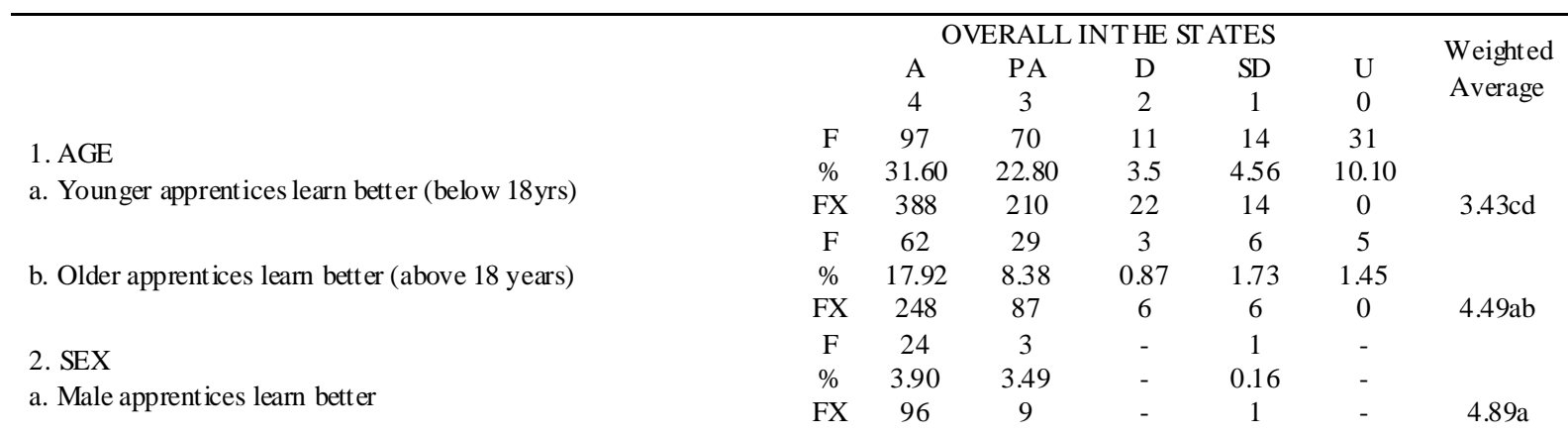




\begin{tabular}{|c|c|c|c|c|c|c|c|}
\hline \multirow{3}{*}{ b. Female apprentices learn better } & $\mathrm{F}$ & 21 & 18 & 14 & 27 & 36 & \multirow[b]{3}{*}{$2.60 \mathrm{e}$} \\
\hline & $\%$ & 13.04 & 11.18 & 8.70 & 16.77 & 22.36 & \\
\hline & FX & 84 & 54 & 28 & 27 & 0 & \\
\hline \multirow{3}{*}{$\begin{array}{l}\text { 3. PERIOD OF APP RENTICESHIP } \\
\text { a. Staying longer means knowing better }\end{array}$} & $\mathrm{F}$ & 36 & 16 & 2 & 12 & 2 & \multirow{6}{*}{ 4.59ab } \\
\hline & $\%$ & 11.21 & 4.98 & 0.62 & 3.74 & 062 & \\
\hline & FX & 144 & 48 & 4 & 12 & 0 & \\
\hline \multirow{3}{*}{ b. Staying shorter means knowing less } & $\mathrm{F}$ & 42 & 37 & 10 & 9 & 14 & \\
\hline & $\%$ & 17.43 & 15.35 & 4.15 & 3.73 & 5.81 & \\
\hline & FX & 168 & 117 & 20 & 9 & 0 & \\
\hline \multirow{3}{*}{$\begin{array}{l}\text { 4. EDUCAT IONAL } \\
\text { a. No formal education extends learning period }\end{array}$} & $\mathrm{F}$ & 22 & 21 & 8 & 7 & 2 & \multirow{5}{*}{$3.62 \mathrm{~cd}$} \\
\hline & $\%$ & 24.18 & 23.08 & 8.79 & 7.69 & 2.20 & \\
\hline & FX & 88 & 63 & 16 & 7 & 0 & \\
\hline \multirow{3}{*}{$\begin{array}{l}\text { b. Primary school leavers learn betterthan people with no formal } \\
\text { education }\end{array}$} & $\mathrm{F}$ & 26 & 31 & 16 & 2 & 5 & \\
\hline & $\%$ & 16.35 & 19.50 & 10.06 & 1.26 & 3.14 & \\
\hline & FX & 104 & 93 & 16 & 7 & 0 & \multirow[t]{2}{*}{$3.87 \mathrm{bc}$} \\
\hline \multirow{4}{*}{ c. JSS3 apprentices learn betterthan pry school learners. } & $\mathrm{F}$ & 10 & 15 & 3 & 1 & 7 & \\
\hline & $\%$ & 22.22 & 33.33 & 6.67 & 2.22 & 15.56 & \multirow[t]{3}{*}{ 3.04de } \\
\hline & FX & 40 & 45 & 6 & 1 & 0 & \\
\hline & $\mathrm{F}$ & 11 & 8 & 4 & 2 & 7 & \\
\hline \multirow[t]{2}{*}{ d. SS3/WASC holders learn betterthan JSS3 } & $\%$ & 26.19 & 19.05 & 9.52 & 4.76 & 16.67 & \multirow{3}{*}{ 3.05de } \\
\hline & FX & 44 & 24 & 8 & 2 & 0 & \\
\hline \multirow{3}{*}{ e. Technical college apprentices leam better than SS3/WASCE } & $\mathrm{F}$ & 7 & 12 & 4 & 2 & 7 & \\
\hline & $\%$ & 8.43 & 14.46 & 4.82 & 2.41 & 8.43 & \multirow{3}{*}{$3.96 \mathrm{bc}$} \\
\hline & FX & 28 & 36 & 8 & 2 & 0 & \\
\hline \multirow{3}{*}{ f. NDE apprentices leam better than Technical college apprentices } & $\mathrm{F}$ & 3 & 5 & 4 & 5 & 13 & \\
\hline & $\%$ & 8.57 & 14.29 & 11.43 & 14.29 & 37.14 & \multirow{3}{*}{$1.86 f g$} \\
\hline & FX & 12 & 15 & 8 & 5 & 0 & \\
\hline \multirow{3}{*}{ g. NCE apprentices learn better than technical college apprentices } & $\mathrm{F}$ & 1 & 2 & 5 & 10 & 18 & \\
\hline & $\%$ & 2.5 & 5.0 & 12.5 & 25.0 & 45.0 & \multirow{3}{*}{$1.25 \mathrm{gh}$} \\
\hline & FX & 4 & 6 & 10 & 10 & 0 & \\
\hline \multirow{3}{*}{ h. Polytechnic apprentices learn better than NCE apprentices } & $\mathrm{F}$ & 1 & 1 & 3 & 9 & 20 & \\
\hline & $\%$ & 2.70 & 2.70 & 8.11 & 24.32 & 54.05 & \\
\hline & $\mathrm{FX}$ & 4 & 3 & 6 & 9 & 0 & $1.00 \mathrm{~h}$ \\
\hline & $\mathrm{F}$ & 1 & 1 & 2 & 10 & 16 & \\
\hline i. University apprentices learn better than polytechnic apprentices & $\%$ & 3.33 & 3.33 & 6.67 & 33.33 & 53.33 & \\
\hline & FX & 4 & 3 & 4 & 10 & 0 & $0.70 \mathrm{~h}$ \\
\hline & $\mathrm{F}$ & - & - & 1 & - & - & \\
\hline Ldnguage or mstruction & $\%$ & - & - & 0.30 & - & - & \\
\hline & FX & - & - & 2 & - & - & $4.99 \mathrm{a}$ \\
\hline & $\mathrm{F}$ & 1 & - & - & 3 & - & \\
\hline b. Igbo language aids learning & $\%$ & 20.0 & - & - & 60.0 & - & \\
\hline & FX & 4 & - & - & 3 & - & $2.40 \mathrm{ef}$ \\
\hline & $\mathrm{F}$ & - & - & - & 1 & - & \\
\hline c. Hausa language aids learning & $\%$ & - & - & - & 33.33 & - & \\
\hline & FX & - & - & - & 1 & - & 3.67cd \\
\hline & $\mathrm{F}$ & - & - & - & 3 & - & \\
\hline d. Pidgin English aids learning & $\%$ & - & - & - & 20.0 & - & \\
\hline & FX & - & - & - & 3 & - & 4.20abc \\
\hline & $\mathrm{F}$ & 1 & - & - & 2 & - & \\
\hline e. English language aids learning & $\%$ & 4.76 & - & - & 9.52 & - & \\
\hline & $\mathrm{FX}$ & 4 & - & - & 2 & - & 4.57ab \\
\hline
\end{tabular}

Source: FieldSurvey (2009)

Means of the same letter within the same column are not significantly different $(F=86.70, p<0.05)$.

JSS: Junior Secondary School SSS: Senior Secondary School WASC: West African School Certificate

NDE: National Directorate of Employment NCE: National Certificate of Education

Key: Undecided $(U)=0$, Strongly disagree $(S D)=1$, Disagree $(D)=2$, Partially agree $(P A)=3$, Agree $(A)=4$, Strongly agree $(S A)=5, F=F r e q u e n c y, X=$ Likert scale value.

It can also be inferred that they strongly agreed that Yoruba as a language of instruction aids apprentices' learning; and that Pidgin English as well as English language aid apprentices' learning. However, the latter two factors do not appear plausible as the frequencies of responses were low.

Similarly, such factors as younger apprentices below 18 years learning better (3.43), staying shorter and knowing less (3.95), no formal education extending learn ing period (3.62), primary school leavers learning better than those without formal education (3.87), JSS (Junior Secondary School) 3 apprentices learning better than primary school leavers (3.04), SSS (Senior Secondary School) 3/WASC (West African School Certificate) holders learning better than JSS3 (3.05), and technical college apprentices learning better than SSS3/WASC (3.96) are significantly the same ( $\mathrm{F}=86.70$, $\mathrm{p}$ $<0.05$ ). The master mechanics partially agreed that younger (below 18 years) apprentices learn better; shorter period of 
apprenticeship means knowing less; having no formal education extends learning period; and primary school leavers learn better than apprentices with no formal education. There was no significant difference in the level of agreement $(\mathrm{F}=86.70, \mathrm{p}<0.05)$. In the same vein, they partially agreed that apprentices with JSS3 certificates learn better than those with primary school certificates; holders of SSS3 learn better than those with JSS3; and technical college graduates learn better than apprentices with SSS3 certificates. However, master mechanics also disagreed that female apprentices learn better (2.60) than male apprentices.

The other factors such as NDE (National Directorate of Employment) apprentices learning better than technical college graduates (1.86), NCE (National Certificate of Education) apprentices learning better than technical college graduates (1.25), polytechnic graduates learning better than NCE graduates (1.00) and university graduates learning better than polytechnic graduates $(0.71)$ were also significantly the same $(F=86.70, p<0.05)$. This suggests that the master mechanics strongly disagreed that NDE apprentices learn better than technical college apprentices; and strongly disagreed also that NCE apprentices lea rn better than technical college apprentices. Similarly, they strongly disagreed that polytechnic apprentices learn better than NCE apprentices, and strongly disagreed also that university apprentices learn better than polytechnic apprentices.

\subsection{Technol ogical Learning Among Skilled Workers, Journeymen and Apprentices}

Table 5 presents technological learning among skilled workers, journeymen and apprentices. In the table, the skilled worker is distinguished from the journeyman and apprentice. The skilled worker, is a master mechanic in his own right, but working with another master mechanic who owns a workshop because he does not own one presently, whereas the journeyman is a fresh or stale graduate without a workshop still working under his own master or another master. A total of 327 people were interviewed in this category though responses varied. The breakdown as shown in Table 5 revealed that $2.82 \%, 26.02 \%$ and $71.16 \%$ of these were skilled workers, journeymen and apprentices respectively. Majority (71.15\%) had not graduated from their masters and most (61.98\%) of them signed a period of apprenticeship of between 3 and 4 years. Similarly, majority (47.18\%) of the skilled workers and journeymen spent between 3 and 4 years under their masters to learn auto-mechanic work. Table 6 depicts the mode of learning and language of instruction employed by their masters. The system of learning was mostly $(99.54 \%)$ on-the-job and this comprised mainly of watching the master working (24.47\%), watching the senior apprentices working (23.35\%), carrying out small tasks (24.34\%), dismantling and coupling of engine parts (16.48\%), as well as verbal instructions from masters and seniors $(11.36 \%)$.

Table 5. Technological learning among skilled workers, journeymen and apprentices

\begin{tabular}{|c|c|c|c|c|}
\hline & Osun & Ogun & Lagos & Total \\
\hline \multicolumn{5}{|l|}{ 1. Class of skill } \\
\hline a. Skilled worker & 1 & 3 & 5 & $9(2.82 \%)$ \\
\hline b. Joumeyman & 30 & 21 & 32 & $83(26.02 \%)$ \\
\hline c. Apprentice & 117 & 62 & 48 & $227(71.16 \%)$ \\
\hline Total & 148 & 86 & 85 & $\mathrm{~N}=319$ \\
\hline \multicolumn{5}{|l|}{ 2. Level } \\
\hline a. Graduated from mechanic work & 31 & 20 & 37 & 88 (28.85\%) \\
\hline b. Not yet graduated & 116 & 60 & 41 & 217 (71.15\%) \\
\hline Total & 147 & 80 & 78 & $\mathrm{~N}=305$ \\
\hline \multicolumn{5}{|l|}{ 3. Years signed for apprenticeship } \\
\hline a. $1-2$ years & 6 & 1 & 4 & $11(4.55 \%)$ \\
\hline b. $3-4$ years & 60 & 49 & 41 & $150(61.98 \%)$ \\
\hline c. $5-6$ years & 40 & 9 & 15 & 64 (26.45\%) \\
\hline d. Above 6 years & 12 & 1 & 4 & $17(7.02 \%)$ \\
\hline Total & 118 & 60 & 64 & $\mathrm{~N}=242$ \\
\hline \multicolumn{5}{|c|}{$\begin{array}{l}\text { 4. Years spent to leam work (skilled workers and } \\
\text { journeymen) }\end{array}$} \\
\hline a. $1-2$ years & 27 & 5 & 4 & 36 (25.35\%) \\
\hline b. 3 - 4years & 27 & 20 & 20 & 67 (47.18\%) \\
\hline c. $5-6$ years & 11 & 7 & 12 & 30 (21.13\%) \\
\hline d. Above 6 years & 8 & - & 1 & 9 (6.34\%) \\
\hline Total & 73 & 32 & 37 & $\mathrm{~N}=142$ \\
\hline \multicolumn{5}{|c|}{ 5. Remaining period of apprenticeship } \\
\hline a. $1-6$ months & 5 & 1 & 5 & $11(7.75 \%)$ \\
\hline b. 6 months $-1 \mathrm{yr}$ & 22 & 3 & 4 & 29 (20.42\%) \\
\hline c. $1-3 y r s$ & 13 & 12 & 8 & 33 (23.24\%) \\
\hline d. 3yrs and above & 38 & 20 & 11 & 69 (48.59\%) \\
\hline Total & 78 & 36 & 28 & $\mathrm{~N}=142$ \\
\hline
\end{tabular}

Source: Field Survey (2009) 
Table 6. Method of learning by apprenticeship in the auto-mechanic work

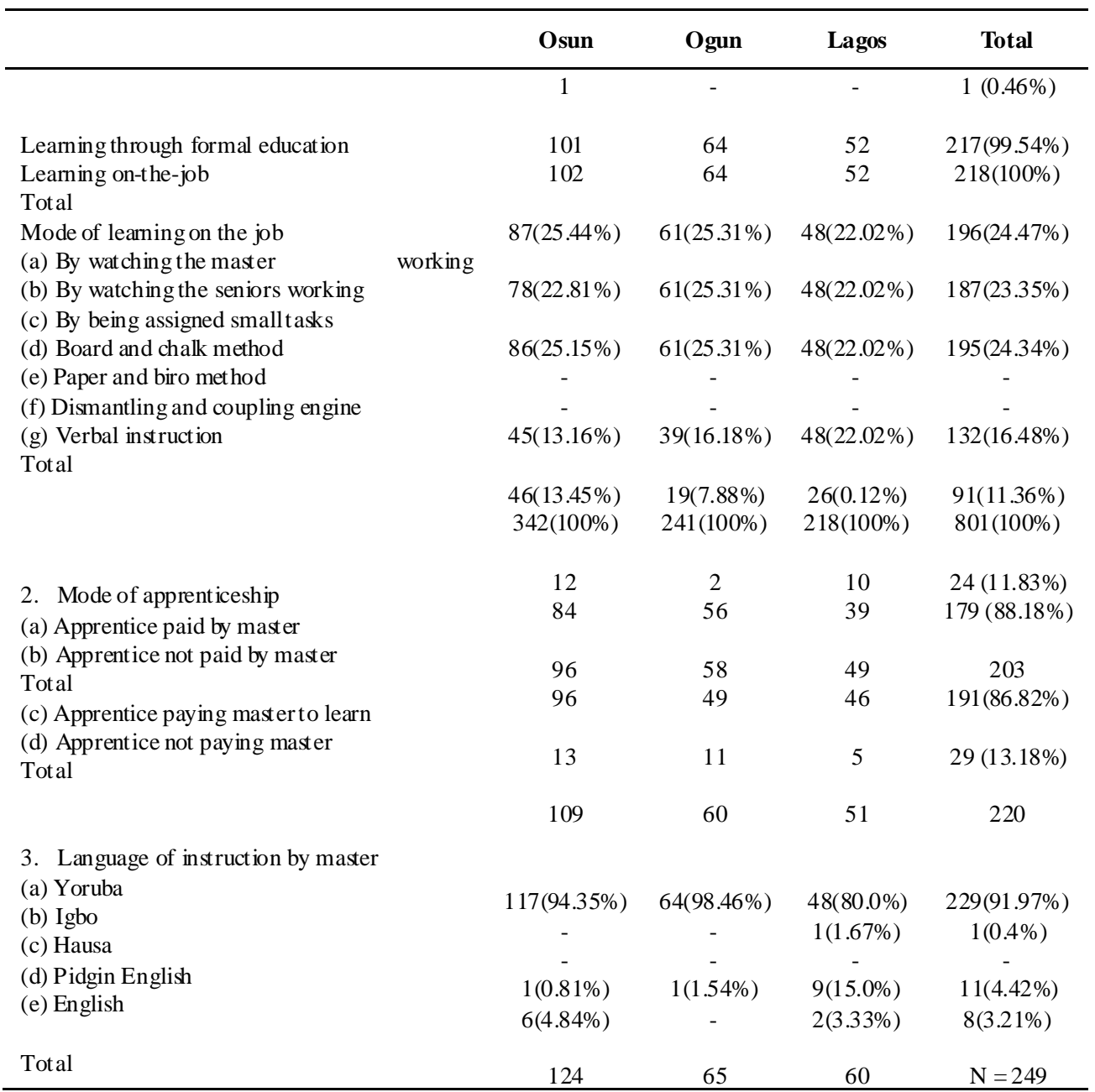

Source: Field Survey (2009)

Table 7. Activities of skilled workers and journeymen during apprenticeship

\begin{tabular}{lcccc}
\hline & Osun & Ogun & Lagos & Total \\
\hline Formal (School) learning & 4 & 1 & 1 & $6(6.19 \%)$ \\
On-the-job learning & 30 & 26 & 35 & $91(93.81 \%)$ \\
Total & 34 & 27 & 36 & 97 \\
Mode of learning on the job & & & & \\
a Document at ion of technical & 2 & 4 & 1 & $7(1.99 \%)$ \\
knowledge & & & & \\
b Research and development & 3 & 1 & 1 & $5(1.42 \%)$ \\
Tightening and loosening & 22 & 23 & 33 & $78(22.16 \%)$ \\
Dismantling & 12 & 14 & 28 & $54(15.34 \%)$ \\
Assembling & 10 & 13 & 31 & $54(15.34 \%)$ \\
Chalk and board & 1 & - & - & $1(0.28 \%)$ \\
Watching master & 23 & 24 & 32 & $79(22.44 \%)$ \\
Demonstration by master & 20 & 5 & 5 & $30(8.52 \%)$ \\
By asking questions & 9 & 14 & 21 & $44(12.50 \%)$ \\
Total & 102 & 98 & 152 & 352 \\
\hline
\end{tabular}

Source: Field Survey (2009)

Most (86.82\%) apprentices paid their masters to learn auto-mechanic work and the language of instruction adopted mostly (91.97\%) by their masters was Yoruba language. In a similar vein, majority (93.81\%) of the skilled workers and journeymen learnt auto-mechanic on-the-job (Table 7).
These were mainly through learning-by-doing activities such as tightening and loosening (22.16\%), dis mantling and assembling (15.34\%), and observing their masters (22.44\%). Their mode of apprenticeship was majorly $(90.11 \%)$ by paying a learning fee to their masters. Most (85.87\%) of 
them were not paid daily stipends by their masters. While some masters did not collect any fee, some masters claimed they did in order to secure commitment from the apprentices. The above facts showed that learning in the auto-mechanic trade tended to be more of tacit by master mechanics, skilled workers and apprentices.

\section{Conclusions}

The study concluded that the Yoruba language played a major role in aiding technological learning for both master mechanics and apprentices in the study area. This was actually the preferred language of learning and instruction. The implication of the above is that the instructors (master mechanics) are able to communicate better, while the learners (apprentices) are able to assimilate better. Older apprentices (above 18 years) were reckoned to learn better than younger ones, while longer stay of apprenticeship was agreed to engender better learning. Age, no doubt, plays a crucial role in learning as young people tend to mature as they grow older. Young apprentices generally spend longer periods in their apprenticeship. As the period of apprenticeship increases, learners could come across greater challenges which they might not have encountered if their periods of apprenticeship had it been shorter. It was partially agreed that lack of formal education extends learning period and that apprentices with formal education learn better than those without. It has therefore become imperative to encourage formal education in the auto-mechanic trade before embarking on apprenticeship.

\section{Policy Recommendations}

(i) In view of the above findings it is recommended that indigenous language be encouraged as a medium of learning especially in informal vocational learning. This is even more so as both the master mechanics and apprentices preferred this.

(ii) Apprentices should be encouraged to acquire basic formal education before embarking on apprenticeship in a craft or trade. The study has shown that apprentices with basic formal education were rated as possessing greater capability to understand auto-mechanic learning.

(iii) Technical education could better enhance vocational competence among the auto-mechanics. It is therefore recommended that a dual apprenticeship scheme (DAS) be introduced to achieve this. DAS would ensure a good balance between theory and practice among the auto-mechanics, a situation that could enrich learning and enhance competence.

\section{REFERENCES}

[1] Akerele, W.O.; “Learning and technological knowledge acquisition in Nigeria's small and medium enterprises: the case study of manufacturing enterprises in Oy o state," NISER Monograph Series, no. 7, 2003.

[2] Akinbinu, A.F.; “Technological learning in Nigerian passenger car industry: an assessment,” NISER Monograph Series no. 12, 2001.

[3] Arthur, J.; "English in Botswana primary classrooms: functions and constraints," in Teaching and Researching Language in African Classrooms, C.M. Rubagumya, Ed. Brigend: WBC, 1994.

[4] Ayodele, S.O.; "The language question and Nigerian education," Oyo State College of Education Public Lecture Series no. 4, 2004.

[5] Barber, J. (2004): "Skill upgrading within informal training: Lessons from the Indian auto mechanics,” International Journal of Training and Development, vol. 8, pp. 128-139, 2004.

[6] Bell, M. and K. Pavitt, “Accumulating technology capability in developing countries," Industrial and Cooperative Chan ge, vol. 2, pp. 35-44, 1993.

[7] Bokamba, E.G.; "The politics of language planning in Africa: critical issues for the 21st century," in Discrimination through language in Africa? Perspectives on the Namibian experience, M. Putz, Ed. Berlin: Walter de Gruyter, 1995.

[8] Callanan, M., C. Cervantes, and M. Loomis, "Informal learning," Wiley Interdisciplinary Reviews, vol. 2, pp. 646-655, 2011.

[9] Dart, F.E. and P.L. Pradham, "Cross cultural teaching in science,” Science, vol. 3763, pp. 649-656, 1976.

[10] Ducatel, K.; "Learning and skills in the knowledge economy," Danish Research Unit for Industrial Dynamics, working paper, February, 1998.

[11] Enos, J.L. (1991): The creation of technological capability in developing countries. London: International Labour Organisation.

[12] International Labour Organisation, “C169 Indigenous and Tribal Peoples Convention, 1989”, Retrieved 4/14/12 World Wide W eb,http://www.ilo.org/ilolex/cgi-lex/convde.pl?C169

[13] Jegede, O.J.; "Science education in nonwestern cultures: towards a theory of collateral learning," in What is Indigenous Knowledge?: Voices from the Academy, L.M. Semali and J.L. Kincheloe, Eds. New York: Falmer Press, 1999.

[14] Lall, S.; Learning to industrialize: the acquisition of technological capability by India, London: Macmillan, 1987.

[15] Marsick, V.J.; "Informal strategic learning in the workplace,” in Work-Related Learning, J.N. Streumer, Ed. New York: Springer, 2006.

[16] Mazrui, A.M. and I.N. Shariff, The Swahili: idiom and identity of an African people, New York: Africa World Press, 1994.

[17] Mazrui, A.; “The African renaissance: a triple legacy of skills, values and gender,” in Africa Bey ond 2000, S.C. Saxena, Ed. Delhi: Kalinga, 2001. 
[18] Mule, L.; "Indigenous languages in the school curriculum: what happened to Kiswahili in Kenya?," in What is Indigenous Knowledge?: Voices from the Academy, L.M. Semali and J.L. Kincheloe, Eds. New York: Falmer Press, 1999.

[19] Ntarangwi, M.; "The challenges of education and development in post-colonial Kenya," Africa Development, vol. 3/4, pp. 211-228, 2003.

[20] Nyamnjoh, F.B.; “A relevant education for African development-some epistemological considerations,” Africa Development, vol. 1, pp.161-184, 2004.

[21] Oyelaran-Oyeyinka, B.; Learning to compete in African industry: institutions and technology in development. Hamp shire: Ashgate, 2006.

[22] Peterson, D., "Dorobo Fund for Tanzania”, Retrieved 4/14/12 World Wide Web, http://www.dorobofund.org/publicationsand-reports1/NELE99.DOC.
[23] Semali, L.M. and J.L. Kincheloe, "What is indigenous knowledge and why should we study it?," in What is indigenous knowledge?: Voices from the Academy., L.M. Semali, and J.L. Kincheloe, Eds. New York: Falmer Press, 1999.

[24] Van Der Heijden, B., J. Boon, M. Van Der Klink, and E. Meijs, "Employability enhancement through formal and informal learning: an empirical study among Dutch non-academic university staff members," International Journal of Training and Development, vol. 13, pp.19-37, 2009.

[25] Viergever, M.; "Indigenous knowledge: an interpretation of views from indigenous peoples," in What is Indigenous Knowledge?: Voices from the Academy, L.M. Semali, and J.L. Kincheloe, Eds. New York: Falmer Press, 1999.

[26] Zambarloukos, S. and A. Constantelou, "Learning and skills formation in the new economy: evidence from Greece," International Journal of Training and Development, vol. 6, pp. 240-253, 2002. 